\title{
Håbets mellemrum
}

\section{Nutid og fremtid i Grundtvigs tolkning af hå bsbegre- bet}

\author{
Af Christian Højlund
}

\section{Indledning}

Håbsbegrebet er, som det fremgår af følgende definitioner, vanskeligt at tolke præcist. Det skyldes, at hå bet alment betragtet er betinget af en ren fremtidig og usikker opfyldelse. Det defineres således i ordbøgerne som en "følelse af forventning ell. formodning m.h.t. noget tilkommende" - eller som "Tanken paa, Udsigten til, Forventningen om et fremtidigt, usikkert Gode « ${ }^{1}$. Håbet er her helt og aldeles bundet til en usikker fremtidsopfyldelse. Det kan selvfølgelig være mere eller mindre velbegrundet, dvs. have mere eller mindre bund i virkeligheden, som den er, men det kan også, når alt andet er opgivet, leve videre som et desperat ønske om, at situationen alligevel vil ændre sig til det bedre.

Ofte domineres begrebet også i kristelig sprogbrug af dette fremtidsaspekt. Blader man salmebogen igennem, bliver det hurtigt klart, at hå bet uden for Grundtvigs salmer ikke er et særligt præcist formuleret begreb. Det bruges som regel om den evighedslængsel og forventning om sjælens frelse, der skal gøre tiden mere tålelig:

Af Skriften har vi trøst og håb

tålmodelig at lide,

om end blandt trængsel, suk og råb

vi tiden her skal slide.

(Kingo, DDS 230,2) 
Håbet hører så at sige til den troende pilgrims udstyr på vandringen frem mod befrielsen:

Igennem nat og trængsel går sjælens valfartsgang med stille håb og længsel, med dyb forventnings sang;

(Ingemann, DDS 340,1)

Også Grundtvig kan bruge håbet $\mathrm{i}$ denne betydning. Men han bryder på afgørende vis såvel med den almindelige verdslige forståelse som med det håbssyn, der har rod i det ortodoks-pietistiske pilgrimssyn. Hans forståelse af menneskets plads i skabelsen og historien bliver en anden end Kingos og specielt Brorsons. Selv om menneskets håb ligger bundet $\mathrm{i}$ hjertedybet, dødt og forvildet, så er det dog et herlighedshåb, der i sig rummer skabelsens oprindelige gudbilledlighed. Det kan derfor røres og vækkes, når det i dåben møder det eneste sande og fuldkomne gudbillede, Jesus Kristus, 'Guds Herligheds Haab'. For Jesus Kristus er historiens midte. Han har en gang for alle kastet lys over det eskatologiske håbs vej fra skabelsens herlighed til fuldendelsens endnu større herlighed. $\mathrm{Ja}$, han er selv dette håb og denne vej. Kun når dåbstroen favner dette 'Guds Herligheds Haab', kan menneskets håb løses fra mørket, vinde retning og vokse som et kristeligt håb, der lader nattevandrerens frygt og bekymring bag sig. Men mørket er stadig en realitet; døden som den sidste fjende ikke endeligt bekæmpet. Derfor må den døbte bestandig vende tilbage til dåbens genfødsel, som er en barnefødsel uden værn mod mørke og ondskab. Og dog er det dødsbetvingeren Kristus, der fødes:

Er spæd du kun hos os endnu, som håbet, der fattes end vinger, Guds Søn er dog sandelig du, og Himmelens hær dig omringer; at løse vort bånd så godt som Guds hånd formår den almægtiges finger. 
Håbet har altså ikke hos Grundtvig mistet karakteren af fremtidig eskatologisk forventning. Men denne forventning er gjort levende og nærværende, fordi den kun kan hente sit liv ét sted fra: Jesus Kristus, sådan som han $\mathrm{i}$ dåben fødes som et spædt og værgeløst håb, og sådan som han herliggjort er til stede ved nadveren. Nadverens enhed og fællesskab med den herliggjorte K ristus er foregribelsen af håbets opfyldelse og mål. Grundtvig tillægger herved håbet en ny dimension, idet han bevæger det som det personificerede Kristushåb fra dets position som ren fremtidsforventning ind $\mathrm{i}$ mennesket og menigheden som en gudsrigekraft. Hans forkyndelse har ikke håbet som emne, men bryder frem af håbsåbenbaringen ved gudstjenestens sakramenter som erfaret baggrund. Den er ikke baseret på tør teologisk spekulation, men på en erfaret genfødsel og opvækkelse af det døde og forvildede håb. Håbets udtryk ændres derfor fra bekymring til lovsang. Det sker klarest i salmerne, der netop, som Grundtvig selv siger det, skal "udtrykke den levende Følelse af, at vi allerede ere overgangne fra Døden til Livet «². For den, der allerede er gået over fra døden til livet, er der ikke mere plads til bekymrede spekulationer over de sidste tider (eskatologien), men nok til det eskatologiske håb, som er Jesus Kristus. I det håb skal livet leves, døden besejres, og den endelige herlighed nås. I det håb bliver det eskatologiske gudsrige til virkelighed midt i en verden, hvor forkrænkelighed, død og mørke hersker. Som sådan skal forkyndelsen i Grundtvigs 'hå bssalme' forstås. Det er målet for denne gennemgang at gøre rede for Grundtvigs brug af håbsbegrebet i salmerne, hvorfor Sangvarket naturligt bliver hovedkilden. Men inden vi kan nå dertil, er det nødvendigt at følge håbsbegrebets udvikling i Grundtvigs prædikener fra 1810-1837.

\section{I}

Som ved de fleste andre begreber i Grundtvigs teologi hænger afklaringen af håbsbegrebet sammen med opdagelserne 1824/25 af 'det levende Ord'. Men det er værd at lægge mærke til, at et ændret syn kan spores helt tilbage til advent 1822 , hvor Grundtvig kommer til København som præst. Her tages kampen mod rationalisterne for alvor op, og det er i opgøret med dyds- og udødelighedslæren, 
den nye håbsprædiken fødes som kampvåben. Den, der sætter sit håb til sig selv, er en dåre. Det vidste Grundtvig af bitter erfaring fra den religiøse krise 1810/11. Men det var netop, hvad rationalisterne gjorde, idet de dyrkede et individualistisk udødelighedshåb, der ganske vist skyldtes det store forbillede Jesus, men hvis opfyldelse til syvende og sidst afhang af menneskets egen dyd og indsats. Sådan som f.eks. H.G. Clausen havde prædiket det:

"Jesus kom, og henvendte Menneskets Blik paa hint bedre Liv hinsides Tiden, paa hin salige Udødelighed, som den jordiske Dyds ene sikre Løn. Og nu vaktes Haabet i den menneskelige Sjel«?

Med denne lære havde rationalisterne formørket menighedens tro og håb. De havde taget håbet fra menigheden og gjort det til et tomt verdsligt håb. Det formulerer Grundtvig selv l.s. i fasten 1823, hvor modstanderne udpeges med stor skarphed:

"Ja, den Kiødets Sands var det, som, under det pralende Navn, af reen Fornuft anmassede sig Aandens Stol og Myndighed og stræbde, under Skin af Oplysning, at fremkogle et kunstigt Mørke ved Middags-Tid, Mørke over Lyset i den hellige

Skrift, Taager for Menighedens Øine,« (s. 4-5).

Det er ikke fornuften som sådan, Grundtvig har noget imod, men kun den fornuft, der skilt fra hjertet og overladt til sig selv er "magtesløs, er blind og raadvild i alle Ting som høre til Guds Rige« (s. 13). Opgøret er et bredt anlagt opgør med den rationalistiske opfattelse af Jesu guddommelighed, så Gud i Kristus som et moralsk forbillede i grunden hverken kan være vred eller nådig, "at egenlig kan ingen Frelser hjelpe os, saa vi maa selv med Dyd og gode Gierninger, saa godt vi kan, fortjene Himmerig“ (s. 10-11).

Allerede i prædikenerne fra 1811-15 kan denne front spores. Skillelinjen går mellem 'Fornuftreligionen og Verdensklogskaben' og de få, "som ere alvorlig og inderlig bekymrede for den udødelige Sjæl, som er skjult i Støvets Hytte, bekymrede for den hellige alvidende Guds Velbehag og for deres evige Skæbne ${ }^{4}$.

Men Grundtvig har ikke nogen egentlig håbsprædiken at sætte ind $\mathrm{i}$ denne kamp. Kun sjældent nævner han håbet uden for et direkte skriftcitat og da som regel i ortodoks-pietistiske vendinger. Tonen i ovenstående citat er typisk for de tidlige prædikener, hvor håbet mest af alt kommer til at ligne en bekymring for den udødelige sjæls udfrielse af det forkrænkelige legeme og trøsten en salig- 
hedstrøst, der skal overvinde »Frygten for at udfalde af Guds Samfund ${ }^{5}$. Det er, som om det rationalistiske angreb på åbenbaringstroen låser Grundtvig fast i et krampagtigt forsvar for det guddommelige $\mathrm{i}$ den kristne tro og det kristne håb.

Det betyder imidlertid ikke, at perioden 1810-21 er betydningsløs i denne sammenhæng. Blot sker nybruddene hovedsageligt uden for prædikenerne. I 1813 gør Grundtvig, bl.a. i polemik med H.C. Ørsted, op med naturfilosofien, fordi den med sin enhedstænkning sammenblander løgn og sandhed, lys og mørke. Det er Fichte, der hjælper Grundtvig til den erkendelse, at der til stadighed foregår en uforligelig kamp mellem sandhed og løgn. For Grundtvig bliver denne kamp nu det egentlig dualistiske i menneskelivet, hvis hovedfjende er døden. Modsigelsens grundsætning er hermed inddraget som erkendelsesteoretisk regel ${ }^{6}$.

Endelig kan man i udkastene til Verdens Krønike 1812/14 og i Dannevirkeartiklerne 1816-19 følge, hvorledes Grundtvig arbejder sig frem mod et nyt dynamisk historie- og menneskesyn, hvilket får stor betydning for den senere afklarede håbstolkning 7 .

\section{II}

Men Grundtvig kørte efterhånden fast i sit historisk-poetiske arbejde. Ingen syntes at have brug for det, han lavede. Han beskriver selv, hvorledes håbet for folk og kirke langsomt døde $\mathrm{i}$ hans eget indre, så han til sidst "døde hjertelig! «?.

Men da han påny blev kaldet som præst først til Præstø/Skibbinge og siden (advent 1822) til Vor Frelsers Kirke i København, fik han nyt mod, "Mod til at bekæmpe Døden, i mig og omkring mig med Opstandelsens Haab «?. Denne Kamp skulle som i Udby-tiden føres fra prædikestolen, men forkyndelsen er tydeligvis en anden. Det erkendes hurtigt, når man går i gang med de utrykte prædikener fra og med advent 1822:

Lys og fred og glæde er således hovedord i prædikenen til l.s. i advent 1822 . Frelsens nutidighed understreges, og håbet knyttes til den gudsrigevirkelighed, som er kommende, og hvor netop lys, fred og glæde skal herske:

»Ja, med det Lys for Øie som giennembryder Gravens Nat med 
Guds Fred som dæmper alle Storme og med det evige Livs uforkrænkelige Haab, er det umueligt Andet end alt her, som Apostelen siger, at være glade i Bedrøvelse..." (s.12).

Den følgende søndag forsøger Grundtvig for første gang i sin prædikenvirksomhed at behandle det kristelige håbsbegreb positivt og indgående. Teksten til denne aftensangsprædiken er som i 1813 Rom. 15,4-910. Men medens Grundtvig i 1813 tog udgangspunkt i v. 4, og anviste, hvorledes menigheden skulle bruge Skriften for at få den fulde trøst, udlægger han nu, at "Guds Herligheds Haab er hans Menigheds Rigdom « (s. 6) ${ }^{11}$. Episteltekstens rammer er sprængt, idet v. 13 faktisk er brugt som overskrift. Det er bemærkelsesværdigt, at netop dette vers inddrages. Det vidner om den kommende udvikling, hvor den eskatologiske glæde og fred bliver til nutidig virkelighed ved Helligåndens kraft. Denne brydningsprædiken afslører, at Grundtvig har rokket ved håbets transcendente karakter; det er sat i bevægelse og på vej til at blive en kraft i mennesket.

Også i den indre prædikenopbygning kan denne bevægelse følges. Grundtvig må - med sit syn på historien som en dynamisk frelseshistorie - tage sit udgangspunkt hos de gammeltestamentlige profeter. Håbet var for dem et rent fremtidigt begreb, "thi under Lovens Aag og Dødens Dom levede Guds Børn kun i Haabet paa den Frelsning som i Tidens Fylde skulle aabenbares«(s. 1). At håbe var for profeterne at 'bie efter Herren', og livet var for alvor en pilgrimsrejse med håbets morgenstjerne som eneste vejleder. Men hvad skal denne mindelse af de gamle profeter egentlig gavne, spørger Grundtvig:

"Forbigangen er jo det Gamle Testamentes Forventnings Tid, og det Ny alt længe forherliget ved alle Guds Løfters Opfyldelse, Natten er forgangen og Dagen oprundet...Hvorledes skulde vi bie efter Herren, da han er hos os? « (s. 4-5).

Spørgsmålet virker som en forudgribelse af det syn, Grundtvig først når frem til i 1823-24. Det besvares da også hovedsageligt med samme skriftbundne argumenter som i 1813. Også nu gælder det, at håbet kun kan erhverves og bevares ved 'Taalmodigheds og Skriftens Trøst'. Grundtvig var stadig skriftteolog.

Alligevel er et nyt syn på vej. Over for rationalisternes tomme håb stiller Grundtvig 'Guds Herligheds Haab'. Det er et dunkelt begreb, fordi det er 'nedlagt i os' ved skabelsen og ikke afklares helt 
før ved forklarelsen. Men ingen kan unddrage sig dets eksistens. Det er et skabelsesbetinget grundvilkår hos mennesket: "vi have Alle det samme Menneske-Kald og Menneske-Maal som maa kunne følges, som maa kunne naaes af alle dem, der oprigtig elske det, de være saa for Resten Lærde eller Læge, Vise eller Enfoldige «(s. 910). Håbet spændes ud mellem menneskets kald ved skabelsen, hvorfra ethvert hjertes dybeste længsler stammer, og menneskets mål, som er "Lighed med det fuldkomne Menneske-Billede» (s. 9). Det er håbet om "Guds Børns herlige Frihed, og Sandhedens Seier og Kiærligheds Fylde“ (s. 13). Det er fælles for alle, fordi mennesket kender denne sandhed, frihed og kærlighed fra sit eget indre dog uden at forstå dem. Midlet til en forklaring og til at nå målet har kun de kristne med det kristelige håb: "Thi det er Haabet om Guds Herligheds Aabenbarelse i Christus Jesus« (s. 13). I Kristus forklares det skabelseshåb om herlighed, som findes dødt og formørket $\mathrm{i}$ hvert menneskehjerte. I ham har det allerede nået sit mål. Derfor bliver Kristus det fælles og eneste tolkningspunkt for menneskets hå $b^{12}$.

Den nye og kraftige håbsforkyndelse skrumper imidlertid ind de følgende søndage. Skriften er ved at blive et alvorligt problem for Grundtvig. Kan salighedshåbet virkelig bygges på et skrevet ord? Er Skriftens ord ikke også tvetydige i sig selv ligesom ord i alle andre bøger? Forholdet mellem Skriften, embedet og menigheden bliver det gennemgående tema den følgende tid, og hver gang Grundtvig betoner Skriftens autoritet, synes den for ham selv at miste troværdighed som håbsgrundlag. Medens apostlene havde det levende ord fra Herren, så har præsterne kun et skrevet ord og kan derfor fejle. Grundtvig må erkende, at sandheden - med dette skriftsyn - afhænger af udlæggelsen. Juledag 1822 forsøger han at nå bag om Skriftens ord ved at henvise til ordenes klang og tone, fordi ordene i sig selv kun skyggevis betegner det åndelige og usynlige. Skal de blive levende, "da maae vi i Aanden sætte os blandt Hyrderne, da først omskinnes vi med dem af Herrens Herlighed« (s. 6).

Grundtvigs anliggende er ikke at betvivle Skriftens ord, men snarere at fravriste skriftlærdommen det monopol, den mener at have på den sande fortolkning. Salighedshåbet må ikke afhænge af en tilfældig fortolkning, men kun af Gudsordet selv modtaget i barnlig tillid. Forholdet til Gud som et barneforhold bliver under- 
streget i denne jul i forsøget på at nå frem til en ubrydelig enhed og samtidighed mellem evangeliets begivenhed og menighedens situation.

I dette forsvar for den ulærdes ret til at kunne sikre sig sin tros og sit håbs ægthed kommer Ånden så at sige Grundtvig til hjælp. 2.s. i fasten 1823 kalder Grundtvig Ånden for den eneste sande fortolker for mennesket, hvis det blot med dåbsbønnen leder og banker, "da staaer Fortolkeren ved Siden, før vi veed det« (s. 4). Da sørger Anden for den oplysning, der skal til. Det er Grundtvigs svar til de skriftkloge som har sagt, "det nytter ei at læse i Guds Ord, før Man forstaaer det« (s. 3).

Opgøret med skriftlærdommen fortsætter foråret igennem. Skriften er ikke længere håbets grund. 5.s.e. påske 1823 siger Grundtvig: "vi bekiende Troe paa Jesum Christum som det eneste hvorpaa vi bygge vort Saligheds Haab« (s. 5). Og troen kommer hverken af et skrevet ord eller dets udlægning:

"Troen kommer af Hørelsen, og det er Guds Ord, som skal høres men lidet oplyste maatte vi være om vi ei forstode, at det hvorved Troen fødes i os er og det hvorved den næres, styrkes og voxer til at bære Saligheds Frugt“ (s. 13) ${ }^{13}$.

\section{III}

Thodberg har tidligere gjort opmærksom på den nære sammenhæng mellem prædikenerne fra forsommeren 1824 og salmen »Jeg kiender et Land ( (III 86) og på, at dette gennembrud var under forberedelse allerede fra $1821^{14}$. Undersøgelserne af håbsbegrebet tyder på det samme. Men endvidere mener jeg med dem nøjere at kunne bestemme en direkte udviklingslinie, der går fra 4.s.e.trin. 1823 frem til gennembruddet. Der synes således inden for dette tidsrum at være en vis strukturlighed mellem en række prædikener og » De Levendes Land «. Den skyldes, så vidt jeg kan se, at Grundtvig til tankerne om skabelsen, Helligånden og den barnlige tro føjer en kraftig forkyndelse af det kristelige håb som det uforkrænkelige Guds ord, der ved Åndens kraft gøres levende og nærværende. Den levende og nærværende gudsrigeforkyndelse er netop det bærende element i sidste halvdel af "De Levendes Land» og det, der marke- 
rer afstanden til Kingos »Far Verden, far vel«. Grundtvigs opgør ligner Kingos, fordi det er et opgør med alt forkrænkeligt $i$ livet. Men samtidig fjerner han sig med sin håbsforkyndelse mere og mere fra det ortodoks-pietistiske pilgrimssyn. Håbet, der også for Grundtvig havde været den ledestjerne, som den fromme pilgrim vandrede imod, bliver langsomt til det morgenlys, der omgiver menneskelivet, så man allerede nu kan skimte, hvad man ved fuldendelsen skal se klart. Men selv om pilgrimssynet brydes, fastholder Grundtvig livet igennem synet på menneskelivet som en vandring imod klarhed. Der foregår til stadighed en kamp mellem lys og mørke, mellem nat og dag. Men morgenlyset er ved at bryde igennem. Disse morgenbilleder, der ofte knyttes til gennembruddet i 1824, er væsentlige for hå bsfortolkningen fra og med advent 1822 , hvor Rom. 13,12 om morgenens nærhed stod tilbage som et kritisk spørgsmålstegn til Grundtvigs egen håbstolkning (her s. 129). Skriftstedet genfindes i en række prædikener fra denne periode og er med til at underbygge formodningen om en indre sammenhæng imellem dem.

4.s.e. trin. 1823 prædiker Grundtvig over epistelteksten Rom. $8,18-23$. Det er betegnende, at han påny sprænger tekstens rammer ved med v. 24-26 at lægge forkyndelsen af det kristelige håb til tekstens udsagn om det skabelsesbetingede håb, som den forkrænkelige skabning er fælles om. Men den egentlige pointe bliver, at Grundtvig sætter teksten i forbindelse med naturens cyklus.

Prædikenen holdes den 22 juni, dagen før Sct. Hansdag (23. juni), og pludselig slår det Grundtvig, at han, ligesom naturen, har nået sit højdepunkt (han er 40 år). Fra nu af går det mod døden. Ved at citere hele første kapitel fra Prcedikerens Bog giver han sig ind under den forkrænkelige skabnings lov og spørger, om ikke også livet har sine bestemte årstider, sit forår i vuggen og sin vinter i graven. Netop når mennesket er på sit højeste, da oplever det sin sommersolhvervsdag. Problemet er, hvad denne forkrænkelighedsprædiken skal bruges til af en, der ikke i verdens adspredelser vil "glemme og kvæle den Længsel, efter noget Varigt, Fast og Uforkrænkeligt, der som et vidunderligt Mindes-Mærke om Sjælens aandelige, himmelske Udspring, findes i hvert Menneskes Hjerte» (s. 3).

Grundtvig ser det verdslige håbs tomhed, rettet som det er mod forgængelige mål. Den egentlige falskhed er, at mennesket med det 
forsøger at undgå sit eget livs betingelser, at ville 'glemme' og 'kvæle' evighedslængslen. Et sådant håb ender uvægerligt i død og fortvivlelse. Stik modsat vil det imidlertid gå det kristelige håb, som hviler på Guds ord:

"Ja, i dette vidunderlige, himmelsendte Ord holder Aanden,

Guds Aand, sin store Vinter-Solhvervs-Prædiken for Støvets

Børn, og trøster dem over Forkrænkeligheden med det evige

Livs uforkrænkelige Haab« (s. 8).

Dette håb vil ikke som naturen ende i døden, men vil tværtimod vokse i klarhed og stige i kraft, jo mere det ældes: „Saaledes prædiker Aanden Haab« (s. 9).

Vi ser, hvorledes håbet knyttes til vækstmotivet. Det hørte $\mathrm{i}$ forvejen hjemme i en dynamisk frelseshistorie. Men først nu bestemmes væksten kristologisk og desuden som usynlig og åndelig. Den begynder med Jesu fødsel (s. 12), og den ender med enheden i Kristi herlighedslegeme:

"Vi haabe, hvad vi ikke see, at engang,...da skal vor Herres Jesu Christi evige Rige synlig aabenbares,... Vi skal forsamles deri ogsaa med disse vore Legemer... De saaes naturlige men opstaae aandelige, thi de skal vorde ligedannede efter Jesu

Christi Herligheds Legeme« (s. 13-14).

Ved Åndens Kristusprædiken er håbet blevet en kraft i mennesket, en basis for den vækst, som hører hjemme i menigheden:

"Thi boer kun dette Haab levende $i$ os, da veed vi, vor Gierning paa Jorden er ikke forfængelig, thi den er skedt i Herren, da sørge vi ikke derover, at vor Kraft med Aarene forgaaer og vi falde med Støvet men pege rolig paa den yngre Slægt i Herrens Menighed, og sige som Johannes den Døber om Christus: Ham bør det at voxe og mig at aftage« (s. 14).

Denne prædiken må have haft en vis betydning for Grundtvig. I hvert fald refererer han til den 38 år senere i en prædiken til samme søndag. Anledningen er, at denne søndag påny falder ved Sct. Hansdag (4.s.e.trin, 23. juni, 1861) ${ }^{15}$. Det får den gamle Grundtvig til at tænke på sin sommersolhvervsdag i 1823:

"Kristne Venner, vi har nylig havt den længste Dag i Aaret, og det minder mig om, at for mange Aar siden, da Sommer-Solhverv ligesom i Aar faldt tæt ved denne Søndag med Epistelen om det dybe Suk over Forkrænkeligheden af alt, hvad vi i denne Verden har kjært, og da især vort eget Legeme... da slog 
det ned hos mig som et Lyn: at netop naar vi staar i vores fulde

Manddomskraft og travle Virksomhed, da har vi vores fulde

Sommer-Solhverv..." (s. 14).

Grundtvig bør alene for sin gode hukommelses skyld tages på ordet. Her er virkelig tale om en refleksion, der skal afprøves, ikke for at finde ligheder og forskelle mellem den yngre og den ældre Grundtvig, men for at forstå udviklingen i 1823 noget bedre.

Det slog ned hos ham som et lyn. Midt i sin bedste tid gennemskuede han sit eget livs forgængelighed. Men han var parat til at tage kampen op ${ }^{16}$. I 1861 spørger Grundtvig sig selv, hvorledes han dengang med Prædikeren overhovedet turde udråbe "Menneskelivets sørgelige Vinterdage» (s. 14). Det gjorde han, fordi apostelens tro og trøst også var hans egen. Selv nu, da han er "hartad dobbelt saa gammel« (NB: stemmer med 1823), har han det samme mod, og det skyldes "aabenbar Guds-Ordets Kraft og Skrifternes Trøst« (s. 15). Citatet er oplysende om situationen i 1823. Det var netop oplevelsen af Gudsordets kraft i det lydelige evangelieord, som Ånden prædikede, der gav Grundtvig mod til at ændre den gamle håbsprædiken om 'Skrifternes Trøst' (fra advent 1813 og 1822). Grundtvig var rede til at tage det endelige opgør med den verdslige håbslære, som rationalisterne havde gjort sig til ét med, fordi Skriftens trøst for ham var blevet til nutidig virkelighed i Gudsordets kraft. At håbet er på vej til at blive en indre kraft, betyder, at den eskatologiske virkelighed, der er håbets mål, allerede nu for egribes, ikke ved menneskelig anstrengelse, men ved Gudsordets åbenbaring i Kristus.

Springer vi nu et år frem til prædikenen på 4.s.e. trin. 1824, ser vi, hvorledes Grundtvig med samme tekstgrundlag prædiker kristeligt håb. Men denne gang sker det $\mathrm{i}$ intensiveret og præciseret form. Opgøret kulminerer i denne skarpe konfrontation mellem verdsligt og kristeligt håbsbegreb. Prædikenen er så opfyldt af håbsudtryk, at der, selv når alt andet skæres bort, bliver en grundstruktur tilbage, som i meget snæver forstand kan belyse Grundtvigs håbssyn på dette tidspunkt. Strukturen er gengivet i bilag I A, og ved at følge den kan man se, hvorledes Grundtvig, som i 1823, bruger solhvervsbilleder. Men tonen er langt skarpere og talen om det kristelige håb mere afklaret. Hvad der dengang betegnedes som et levende håb inden $\mathrm{i}$ mennesket og senere blev præciseret til "vort Haab, som er Guds Rige inden i os « ${ }^{17}$, er nu blevet til et personificeret håb: 
"Christus i eder er Herlighedens Haab«. Grundtvig har brugt Kol. 1,27, og det i sig selv er bemærkelsesværdigt. Det er ikke sket før. Ikke desto mindre skal det blive det hyppigst anvendte håbscitat hos Grundtvig.

I virkeligheden tolkes det kendte udtryk 'Guds Herligheds Haab' fra Rom. 5,2, idet det knyttes sammen med Kol. 1,27. Derved ændres den objektive genitiv (hå bet om Guds herlighed) til en subjektiv genitiv (Guds herlighed, åbenbaret i Kristus, avler håb). Håbet har for så vidt ikke ændret karakter, men det har fået en ny dimension - opfyldelsens dimension. Det kristelige håbs sandhed, ægthed og bestandighed sikres af legemliggørelsen i Kristus ved dåben: "Letvingede Haab/Gudbroder! gienfødt i den hellige Daab!« (III 86,10).

Netop det personificerede håb, som det for første gang findes $i$ prædikenen og genfindes i "De Levendes Land «, tyder på en nær sammenhæng imellem dem. Iøvrigt møder man prædikenen igennem associationer til salmen, ikke mindst p.g.a. den strukturlighed, der synes at være, og som jeg mener at kunne genfinde i prædikener fra og med 4.s.e. trin. 1823. Dette er forsøgt fremstillet i bilag I B.

Denne lighed er betinget af, at prædikenerne såvel som salmen er bygget op omkring et 'håbets genskabelsesforløb'. Det begynder med skabelseshåbet eller -længslen, der enten dør eller perverteres, og det ender med den kristologisk betingede genskabelse eller genfødsel. Dette forløb er måske nok beskrevet tidligere af Grundtvig, men han har manglet den kraftige kristelige håbsforkyndelse, der skulle fuldende banen. Det gør han ikke mere:

Letvingede Haab!

Gudbroder! gienfødt i den hellige Daab!

For Reiserne mange til Landet bag Hav,

For Tidender gode, for Trøsten du gav, Lad saa mig dig takke, at Glæde jeg seer, Naar Haab er ei meer!

$$
\text { III } 86,10
$$

Det afgørende ved dette vers er, at pilgrimsbillederne, ligesom i prædikenen ${ }^{18}$, brydes af håbets legemliggørelse i dåben. Landet bag hav er blevet tilgængeligt. Menneskelivets snævre grænser er brudt, og kærlighedens råderum er nu 'Himmel og Jord' (v. 13). Eller som 
Grundtvig siger i prædikenen (jvf. bilag): »Naar Haabet nu saaledes begynder at blive levende i Kiærlighed, da giver det sig til kiende $\mathrm{i}$ hele vort Levnet«.

Denne håbsforkyndelse blev et vigtigt våben $\mathrm{i}$ den kamp, Grundtvig indledte 1822/23 for menighedens tro og salighedshåb imod den skriftlærdom, der med fornuften som skriftfortolker havde forkyndt en selvhjulpen udødelighedstro, der tog kraften ud af evangeliet. Rationalisterne havde med denne tale forvirret menigheden og prostitueret sig med Grundtvigs (og Kingos) værste fjende: 'Kiødets Sands' - den almindelige verdslige forkrænkelighed med dens egoistiske håbsforståelse. Målet for denne forkyndelse var at byde døden trods: "Dit Rige er der hvor man Død byder Trods,/ Det komme til os!« (III 86,11).

\section{IV}

Selv om jeg (af pladshensyn) kun vil ofre få ord på den følgende periode, betyder det ingenlunde, at Grundtvigs håbssyn er endeligt afklaret med gennembruddet i 1824 . Således vil det være umuligt at forestille sig salmernes præcise håbsudlægning uden den nytænkning fra 1832, som Thaning har gjort så kraftigt opmærksom på. På den anden side mener jeg, at denne nytænkning er dybt afhængig af de afklarende elementer, der kan spores i Grundtvigs teologi allerede fra begyndelsen af 1820'erne jvf. bl.a. ovenstående undersøgelser.

Det bliver af stor betydning for Grundtvigs håbsforståelse, at han i 1832 vender sig mod en ny front, nemlig den lutherske ortodoksi ${ }^{19}$. Hvor han tidligere over for rationalisterne forsvarede håbets guddommelighed, forsvarer han nu, i prædikenerne fra 1832, dets sande menneskeliggørelse i Kristus. Det medfører, at det kristelige håb ikke mere som i 1823 går imod naturens orden eller, som han siger advent 1825, "høit over Naturens Orden $\aleph^{20}$, men derimod efter naturens orden, "at det ny Menneske dog skal fødes af det gamle, og det overnaturlige gaa frem i samme Orden som det naturlige« (PF, s. 21).

Det skabte menneskeliv bliver den absolutte forudsætning for, at genskabelsen kan finde sted. Det sker ved Jesu fødsel som sandt 
menneske julenat og ved hans genfødsel i dåben som et spædt og værgeløst håb. Denne ændring kan spores allerede i de senere prædikener fra Søndagsbogen. Sammenligner vi f.eks. prædikenen fra SB, II, s. 88 med dens forlæg fra s.e. nytår 1824, bliver det klart, at mens det i 1824 er frelseren, Herren, den herliggjorte, der fødes som et håb $\mathrm{i}$ hjertet, så er det $\mathrm{i}$ den trykte prædiken 'det ny menneske det spæde barn - det spæde håb - drengebarnet'.

Grundtvig vender sig fra de lutherske fædre til Luther selv. Det handlende Gudsord som et personligt tiltalende ord kommer i centrum. Men det håb, der grundes på et sådant nøgent og værgeløst evangelieord, er også for alvor blevet latterligt i verdens øjne. Ligeså latterligt som det nyfødte Jesusbarn forekom verden. Grundtvig har opgivet ethvert forsvar for kristendommens forrang og særrettigheder. Men han er også i samme øjeblik kommet evangeliets sandhed nærmere - en sandhed, der ikke kan påtvinges nogen, men som selv i det levende ords fri vekselvirkning vil overbevise mennesket. Han er med en håbsforkyndelse, der tager sit udgangspunkt $\mathrm{i}$ en latterlig og værgeløs barnefødsel, kommet mennesket imøde i dets nød og værgeløshed.

I overensstemmelse hermed flyttes håbsprædikenerne i løbet af trediverne hen til tiden imellem jul og faste. Der kan man følge dets spæde fødsel og vækst. En fødsel og vækst, der aktualiseres i gudstjenestens sakramenter.

I gudstjenestens ritualord nutidiggøres evangeliets indhold ${ }^{21}$. Prædikenerne fra trediverne understreger endnu engang og mere omfattende og afklaret frelsens nutidighed - gudsrigets nærhed. Alt i gudstjenesten skal udspringe af denne gudsrigeerfaring i dåb og nadver. Håbets udtryk bliver lovsang. Eller som tidligere udtrykt: Guds herlighed, åbenbaret i Kristus, avler håb:

Syng det, Himmel! Føl det, Jord!

Mal det, Alter-Flamme!

Født i Søndags er Guds Ord,

Lyset med det Samme,

Steget op af Dødens Daab

Igienfødt er Livets Haab!

Himlens, Jordens Morgen-Røde

Stod i Søndags op af Døde

Ved Gud Faders Røst og Raab! 
Ja, hver Søndags Morgen-Gry
Op fra Tunger røde,
Herlighedens Haab i Sky
Far med Toner søde!
Byg paa Haabet, Troens Aand!
Alting nyt med Skaber-Haand:
Soel og Maane, Stjerne-Vrimmel,
Præst og Kirke, Jord og Himmel,
I Fuldkommenhedens Baand!

III 146,3 og 10

Versene stammer fra salmen »Søndag er vor Herres Dag« skrevet $i$ 1837. Den vokser så at sige ud af den inspiration, Grundtvig $\mathrm{i}$ foråret 1837 hentede fra den græsk-ortodokse liturgi, hvor der til hver søndag hører et opstandelsesvers ${ }^{22}$. Søndagens gudstjeneste er blevet til et eskatologisk drama, hvor det samme skaberord, ved hvilket alting blev til, påny skaber liv og Ånd. Dødens magt brydes igen, når hå bet, som er Kristus, står op af 'Dødens Daab'. Og denne erfaring af frelsens nutidighed genføder menighedens håb, der stiger op som lovsang. Fadervor, der nu er blevet håbets udtryk, kan nynnes i erfaringen af bønhørelsens nutidighed ${ }^{23}$.

Forkyndelsen af påsken som håbets fest fejret påny hver søndag bør ikke glemmes, selv om Grundtvig som oftest knytter håbet til julens tekster. Det betyder blot, at påskens budskab også er julens, $\mathrm{ja}$, at det begynder med julens inkarnation. Håbets vækst er spændt ud imellem Guds sande menneskeliggørelse, da han sendte sin søn og udleverede sig helt til mennesket - og menneskets sande guddommeliggørelse i den opstandne og herliggjorte Kristus - i gudstjenesten en vækst mellem dåbens tro, der føder håbet, og nadverens fuldkomne kærlighed, hvor håbet i forudgribelsen af det eskatologiske fællesskab har nået sit mål.

\section{V}

Idet håbsudtrykket ændres fra en usikker fremtidsbekymring til lovsang, har Grundtvig selv vist hen til sine salmer som det sted, hvor det afklarede begreb udfoldes. De skal derfor danne grundlag 
for den følgende systematiske gennemgang. Håbet er i Sangvarket nævnt 530 steder; heraf er de ca. 400 fra 1836/37 og fremefter med en stadig intensivering, således at der alene $i$ bd. V findes 173 steder. Endvidere viser en samlet oversigt, at håbet næsten altid hører hjemme i dåbsterminologien i Grundtvigs salmer. Dåben er "Haabets Moderskiød « hedder det i en påskeprædiken fra $1855^{24}$, og vi vil da også nu koncentrere os omkring håbet som dåbsudtryk:

1

Det genskabelsesforløb, der i 1823-24 gav en række prædikener fælles grundstruktur, kan genfindes inden for en enkelt salmes rammer, hvor håbet bevæges fra et dødt skabelseshåb til et af troen genfødt herlighedshåb, som er Kristus:

Ja, vi troe, men Tvivl sig klæber

Som en $\emptyset$ gle til vor Tro,

Døden spiller os paa Læber,

Hvor vi mellem Skygger boe, Haabet er, som mat det glimter,

Naar bag Sky vi Maanen skimter!

O, lad Troen sig nedsænke

Dybt i Jordans rene Flod!

Da gienfødes Tro saa fage, I det store Trilling-Navn, Vender moderlig tilbage, Med en Gudsøn i sin Favn, Som skal aldrig smage Døden:

Haabet, Guddoms-Morgenrøden!

Jesus! ja, Du vil jo være I os Herlighedens Haab, Fødes, til Gud Faders Ære, Hos os i hver Barne-Daab, Voxe hos os allesammen Op i Sky med Fryd og Gammen! 
Det er omkring denne Kristus-identifikation, Grundtvig bygger sit ændrede håbssyn op. Det er den, han livet igennem vender tilbage til, når menneskets salighedshåb skal tolkes. I Kristus opfyldes håbet, og eskatologiens herlighed åbenbares for mennesket. C.I. Scharling har i Grundtvig-Studier fra 1950 taget stilling til denne nutidiggørelse, idet han spørger, om den ikke problematiserer Grundtvigs eskatologiske syn:

"Herved fremkommer Hovedproblemet i hele det Tema, der beskæftiger os: hvorledes forenes denne Erfaring af Gudsrigets Herlighed her og nu med den stærke eskatologiske Forventning? (s. 30).

Senere skelner Scharling mellem den nutidige eskatologiske erfaring og "det egentlig eskatologiske hos Grundtvig» (s. 32). Men efter min mening er det forkert at adskille disse ting. Eskatologien bliver først egentlig og virkelig for Grundtvig, når dens herlighed erfares som en nutidig kraft $\mathrm{i}$ dåben og nadveren. Man kan altså snarere sige, at nutidiggørelsen løser problemet omkring 'de sidste ting'. For de var et problem for Grundtvig i begyndelsen af tyverne, hvor han følte, at håbet var vildledt og dødt både hos ham selv og menigheden. Skulle modstanderne ikke med rette kunne kalde det kristelige salighedshåb forgængeligt og falskt, måtte der kunne siges noget sikkert om dets mål - og det kunne der. Dåbens og nadverens tilsigelse. blev pantet på, at livet som et liv i håb allerede var begyndt og ikke ville beskæmmes, men ende med evigheden.

Med håbets personificering giver Grundtvig den traditionelle tolkning en drejning, sådan som man kan se det $\mathrm{i}$ den ikke videre spændende gendigtning af Sthens »Du Herre Krist «, hvor linjen »til dig jeg håber ene" hos Grundtvig bliver til "Vort Haab er du alene" (IV 259,1). Eller med et originalt vers: "Vort Haab ei ligner Herren blot/Det er ham selv igrunden«. Men siger man blot håb = Jesus, har man i grunden ikke sagt ret meget. Vi må videre spørge, hvilken betydning dette får for mennesket. Det er da også afgørende, at Grundtvig selv i snævreste forstand sammenholder håbsidentifikationen med det menneskelige håb:

Vor Haab ei ligner Herren blot,

Det er ham selv igrunden,

Med Livets Ord er Livets Drot 
I Hjertet og i Munden

Vort Himmel-Haab er fast som hans

Der kom fra Himlen og med Glands

Til Himmels foer derefter.

$$
\text { V } 156,4
$$

Dette sker, som nævnt, allerede i 1824 med »De Levendes Land», v. 10 , hvor pilgrimsvandringen brydes af håbsopfyldelsen $\mathrm{i}$ dåben. Man kan også med billeder fra 1823/24 sige, at håbet for Grundtvig fastholdes i morgenlyset, i overgangen mellem nat og dag.

Det trues igen og igen af nattens mørke og må hente sit liv fra dagens lys. Denne spænding mellem det allerede opfyldte og det endnu ikke indfriede bliver ved at følge Grundtvigs hå bstolkning. Måske kan man sige, at Grundtvigs syn på historien som dynamisk frelseshistorie kombineret med hans kirke- og sakramentsyn fører til et opgør med det klassiske pilgrimssyn og frem til et selvstændigt syn på livet som en vandring. Sådan vil jeg i hvert fald tolke den kendsgerning, at Grundtvig til stadighed, også efter 1832, kan beskrive håbet i pilgrimsbilleder. Det er f.eks. tilfældet i IV 135, hvor v. 5 om frygt og håb/nat og dag, følges op af pilgrimsmotivet $\mathrm{i} v$. 6-7:

Haabet stige,

Frygten vige

I Vorherres Jesu Navn,

Mens vi skride,

Til vi glide

Ind i Kiærlighedens Havn!

Der er Freden Haabets Frugt,

Der er Frygten udelukt.

Herren være

Priis og Ære,

Lov og Tak evindelig

For hans mange:

"Vær ei bange"

Paa vor Vei til Himmerig!

Han er med os fra vor Daab,

Hos os Herlighedens Haab! 
De to sidste linjer viser, at Grundtvig har gjort op med det alene fremadrettede pilgrimssyn. Det kristologisk tolkede håb har kastet et nyt og afgørende lys ind over vandringen. Håbet er blevet ud tryk for en reel dialektisk spænding. I det indeholdes og sammenholdes eskatologiens 'allerede og endnu ikke'.

2

Thodberg har i sin bog En glemt dimension... vist, hvorledes indholdet i Grundtvigs salmer ofte er præget af det givne dåbsritual ${ }^{25}$. Den nære sammenhæng mellem håbet og dåbsbønnen Fadervor er et resultat af denne bundethed til ritualet og af afgørende betydning for forståelsen af det afklarede begreb. Dog mener jeg, Thodbergs analyse bliver for snæver ved at fokusere så kraftigt på dette ene aspekt. Ritualbundetheden betyder ikke, at man med Thodberg kan slutte:

"...det foreløbige resultat giver os lov til at tolke håb = Fadervor eller herligheds håb = Fadervor selv på steder, hvor ordene håb og herligheds håb står alene, dvs. uden andet i sammenhængen, der peger i retning af Fadervor« (s. 83).

"Ligegyldigt hvor ordet findes, vil det i sig have med en klang af bønnen i Jesu navn og dens forvissning" (s. 84).

Den antagede ritualbundethed styrer her i for høj grad begrebstolkningen. Håbet hører som dåbsudtryk til i en større gudstjenestelig sammenhæng. Dette bliver særligt klart efter den såkaldte græske vækkelse i 1837. Hver søndag blev det eskatologiske håb fulgt fra den spæde begyndelse $\mathrm{i}$ dåben til dets opfyldelse i nadverfællesskabet med den opstandne Kristus. I tyverne blev håbet som regel tolket som den herliggjorte Kristus. I begyndelsen af trediverne måtte dette håb for at blive et sandt tilknytningspunkt for menneskets håb tage sin begyndelse $\mathrm{i}$ det spæde Jesusbarn. Med den græske påvirkning i 1837 blev de to tolkninger for alvor forbundet. Såvel håbets menneskelige og svage begyndelse som dets guddommelige opfyldelse må tages for pålydende og kan ikke adskilles. Noget andet er, at dåbsmotivet er det absolut dominerende. Dette kan vel bl.a. skyldes fronten mod ortodoksien, der får Grund tvig til at understrege skabelsen som forudsætning for genskabelsen, og desuden Grundtvigs stadige fremhævelse af dåbssakramentet som troens kilde. Men i 1837 var det altså den opstandne og herliggjorte, der fyldte håbspersonificeringen ud: 
O, tænk paa os med Tro og Daab!

Ja, Christus! Herlighedens Haab!

Vær selv hos os tilstæde!

O, hør Du os, Korsfæstede!

Opstandne, Himmelfarne!

I 123,7 (græsk salme)

Denne brug af håbsbegrebet fortsætter, også efter at det bindes til dåbsritualet. En enkelt bemærkning fra Christenhedens Syvstjerne (1860) tyder på det samme. Her taler Grundtvig om »Guds Herligheds Haab, som i det andet Corinther-Brev er saa mesterlig betegnet" (udgaven 1955, s. 41).

Udtrykket 'Guds Herligheds Haab' forbindes her med 2.Kor., uden at det ordret findes et eneste sted i brevet. Men det tolkes ifølge Grundtvig dér. Han må tænke på 2.Kor.3 og 4, hvor forholdet mellem den gamle bogstavspagt og den nye åndens pagt behandles $(3,6)$. Det dække, der var over den gamle pagts herlighed er i Kristus blevet fjernet $(3,14)$, og en ny herlighed langt større end den gamle er stillet til skue $(3,18)$.

Det avler håb, der kan udholde alle trængsler $(4,10)$. Det er ved at fødes, dø og opstå med Kristus, herlighedshåbet manifesteres og bliver bestandigt. Det grundlæggende udtryk "Guds Herligheds Haab« bliver Grundtvig så kært, fordi det i sig indeholder målet for håbet - Guds herlighed. Så det, der bestemmer valget af skriftsteder, er for så vidt ikke, om ordet håb er med, men om den kristologisk tolkede gudsherlighed beskrives.

3

Når det er sagt, kan jeg iøvrigt kun tilslutte mig Thodbergs analyse. Håbet har sin ganske bestemte plads i ritualet og tydes derudfra. Det peger Grundtvig selv på, når han i Christenhedens Syvstjerne lader grundordet af Herrens egen mund bestå af "Troes-Ordet nemlig i Daabs-Pagten, Haabs-Ordet med Fredlysningen og Herrens Bøn, og Kiærligheds-Ordet i Herrens Bord-Tale ved den hellige Nadver« (s. 40).

Håbet gemmes i Fadervor og fredlysningen. Fadervor bliver med sin placering i ritualet mellem Mark. 10,13ff. og 1.Peter 1,3 håbets udtryk. Med bønnen af Herrens egen mund går det dåbsbarnet, 
som det gik børnene i Mark 10: de blev taget i favn og velsignet. Det forkyndte gudsrige blev nærværende for dem, der barnligt tog imod det, såvelsom for dåbsbarnet, der stammende bad om dets komme. Dette komme bekræftes med trosbekendelsen, vandøsningen i treenighedens navn og gudsrigets fred, der skænkes i fredlysningen. Fadervor er pantet på denne fred:

Det Tredje Ord er Fredens Pant

For Hjerte og for Tanker,

I "Fadervor" hos Herren fandt

Vort Barne-Haab sit Anker!

V 147,8

Håbet legemliggøres i det hørlige Fadervor (bemærk citationstegn). I det bøjer Jesus sig ned til det mindste menneskebarn og beder med på bønnen, så den gør, hvad den siger - „Saa lever Herlighedens Haab/I Fadervoret inde« (V 61,7). Dåbsbarn og Jesus bliver ét i bønnens ord:
Himlen for det Barn oplader
Helligaanden i vor Daab,
Barnet raaber: Abba, Fader!
Nævnes »Herlighedens Haab«,
Favner alle Barne-Sjæle,
Faaer i Aanden Mund og Mæle
Af Guds-Ordets »Fadervor«.

Jesu Abba-råb sammen med barnet er pantet på opfyldelse. Han kommer $\mathrm{i}$ Helligånden fra faderfavnen og bliver tolken mellem Gud og menneske. Bønhørelsen bliver herved nutidig, og barnet skænkes genfødt håb, arveret og børnekår:

At med himmelsk Barnehaab,

Arveret tillige,

Vi gienfødes i vor Daab,

Fødes til Guds Rige,

Det beviser Fadervor, 
Som os skiænker Børnekaar

Med Guds Førstefødte!

V 175,5

Ved at blive ét med dåbsbarnet solidariserer Jesus sig med det svage og magtesløse menneske. De har dermed fået fælles skæbne og skal vokse sammen. $\mathrm{Og}$ til den spæde begyndelse må den voksne igen $\mathrm{og}$ igen vende sig:

Agt det kun vel! i Jesu Navn

Bedes det maa alle Dage,

Som af et Barn i Jesu Favn,

Der kan hans Kiærlighed smage,

Føler det paa sig, alt hans Haab

Fødtes af Troen i hans Daab,

Voxer med Jesus den lille!

IV 337,2

Det er ovenfor vist, hvorledes 1.Peter 1,3 om det genfødte håb bliver tæt forbundet med Fadervor som vækstens udgangspunkt. Genfødslen betyder, at Jesusbarnet fødes påny:

Da gienfødes Tro saa fage

I det store Trilling-Navn,

Vender moderlig tilbage,

Med en Gudsøn i sin Favn,

Som skal aldrig smage Døden:

Haabet, Guddoms-Morgenrøden!

I 48,16

Men det skal understreges, at dette vers også peger frem i ritualet til Rom. 6,4 om dødens og opstandelsens dåb. Håbet er 'Gudsøn' og 'Guddoms-Morgenrøden' (opstandelsessolen). Kristus er således både vejen (det spæde Jesusbarn, der skal vokse) og målet (den opstandne, hovedet på legemet - målet for væksten).

Selve dåbshandlingen med den tilspørgende trosbekendelse, vandøsningen $\mathrm{i}$ treenighedens navn, iklædningen af 'ChristenHuen' med den efterfølgende bøn og endelig fredlysningen er fuld- 
byrdelsen af det genskabelsesforløb, der forjættende fandt sted i første halvdel af ritualet. Det er selve Åndens gerning - i den skænkes det nye liv, der lige er tilsagt mennesket: "... Saa skal og du vandre i et nyt Levnet " (Rom. 6,4). Derved understreges troen som skænket tro, og bekræftelsen bliver Åndens ja sammen med mennesket på, at troen har modtaget herlighedshåbet i Fadervor. I Fadervor var freden pantet, i fredlysningen bliver den til virkelighed. Den eskatologiske fred, der første gang skænkedes julenat og nu igen er blevet skænket $\mathrm{i}$ dåben:
Hvergang Hjertet jubler ved
Lysningen af "Herrens Fred,“
Hører det fra Engle-Chor:
Gud til Ære, Fred paa Jord!
Finder da, om før ei fundet,
Frelseren med Svøb omvundet,
Finder "Herlighedens Haab»
Født og svøbt i Tro og Daab!
I 201,5

Hvergang den døbte hører fredlysningen og med den vender tilbage til dåbens genskabelse, får freden krop og kan vende sorg og usikkerhed til glæde og tillid:

Det christne Haab paa Fugleviis

Os flyver brat imøde

Paa Veien smal til Paradis,

Naar vore Hjerter bløde,

Det bærer paa sin Vinge Bud

Fra Himmerig og Naadens Gud,

Hans Fred med Budet følger.

IV 225,3

Bemærk den retning, 'Det christne Haab' har. Den afgørende bevægelse er ikke pilgrimmens stræben mod gudsriget, men derimod Kristushåbets bratte nedslag med den gudsrigefred, der allerede her skal vende slagets gang mod død og mørke. Med det følgeskab må vandringsmanden gå sin gudsrigegang og kæmpe sin gudsrigekamp på jorden. 
4

Vi har nu fulgt dåbens genskabelsesforløb bestemt af det givne ritual. Det kommer ligefrem til at præge strukturen i mange af Grundtvigs salmer. I kernen af disse salmer sker der et toneskift. Dåbens under vender forløbet. I dåben møder det skabte, men forvildede menneske med sin bøn, som er et nødråb, genskabelsens herlighed i Jesus Kristus. Han bliver ét med mennesket og beder med på dets bøn, så bønhørelsen bliver nutidig. Genskabelsen sker - håbet vinder retning. Denne struktur gør Lise Helweg rede for s. $247 \mathrm{ff}$. under navnet ' $\mathrm{V}$-struktur'. Alligevel vil jeg lige præcisere, hvad jeg lægger i denne betegnelse. Sagen er jo, at en sådan struktur givet kan opspores overalt i kristen poesi og prosa. Kan man overhovedet tale om en struktur, der er helt speciel for Grundtvig? Jeg mener ja!

Allerede i prædikenerne fra $1823 / 24$ kunne vi se en vis struktur aftegne sig (her s. 131). Den var bestemt af det vekselvirkningsforhold mellem himmel og jord, mellem Gud og menneske, som Grundtvig tidligt forbandt med det lydelige ord. Men først med tredivernes endelig vedkendelse af det skabte menneskeliv som frelsesobjekt og som Guds frelseshistoriske tilknytningspunkt tages den fulde konsekvens af dette syn. Gud måtte i et spædt og værgeløst barn blive sandt menneske, for at genskabelsen kunne finde sted. I denne udleverethed, hvor ethvert forsvar for kristendommen ophører, kan troens under ske og et sandt Kristushåb fødes og vokse. Dette syn danner, så vidt jeg kan se, den nødvendige baggrund for denne specielle $V$-struktur.

"Vor Herre! til Dig maa jeg tye (IV 5) er en af de salmer, hvor strukturen klarest aftegner sig. Det påviser Lise Helweg. Men hvor finder håbet da sin plads i denne sammenhæng? Svaret giver salmen selv: det omgiver de to midtervers, hvor toneskiftet skulle finde sted:

Er spæd Du kun hos os endnu, Som Haabet, der fattes end Vinger,

Guds Søn er dog sandelig Du, Og Himmelens Hær Dig omringer, At løse vort Baand Saa godt som Guds Haand Formaaer den Almægtiges Finger. 
Er spæd Du, vor Herre, saa from, Dit Fadervor kan Du dog stamme Og Alt hvad Du beder Ham om, Han lover og giør med det Samme, Da læges vort Savn, Dit hellige Navn

Ei længer paa Jord er til Skamme. (v. 5 og 8 )

Tonen skifter virkelig. Selv om håbet allerede i v. 5 er det personificerede håb, så ligger det dog som gudbilledet skjult og bundet $\mathrm{i}$ hjertedybet. Det fattes vinger. Men i sidste halvdel af verset peges der på stedet og midlet, der skal løse båndet. Det sker ved korstegnelsen i dåben, hvor gudbilledet løses fra mørket og smelter sammen med korsets gudbillede, der tegnes på hjertet af Guds egen finger ${ }^{26}$. Stedet er menigheden som det Nazareth, hvor håbet som Jesusbarnet skal gro (v. 6), og midlet er dåben, hvor Jesus Kristus beder med på gudsbarnets bøn (v. 7). Det inkarnerede herlighedshåb kan nu lydeligt stige op i Fadervor. Det er spædt og stammende, men Jesu medbeden er pantet på, at bønnen bliver hørt. Truslen fra fjenderne er afværget og gudsforholdet som et barneforhold er genoprettet. Genskabelsen er sket.

Dette forløb, hvor herlighedshåbets konkretisering i dåben muliggjorde væksten og bestemte den kristologisk (det er Jesusbarnet, der vokser) og ekklesiologisk (den dåbsbekendende menighed er hjemmet) kan også indeholdes i et enkelt vers:

Troen, hun er af samme Art, Har og et Skiød for Guds-Ordet, Føder os Haabet aabenbart, Som med Guds Kraft er omgjordet, Haabet opgroer i Herrens Hjem, Bærer med Barnet i Bethlehem Navnet: Gudsherligheds-Haabet!

IV 309,3

5 .

Håbet er frem for noget vækstens symbol hos Grundtvig. Men som Valdemar L. Ludvigsen gør opmærksom på (s. 168) er der tale om 
både en kontinuerlig og en diskontinuerlig vækst. Håbet kan på den ene side ikke beskæmmes, fordi det i Jesus Kristus som begyndelse og mål er frelseshistorisk betinget, men det truer på den anden side med at slå over i misvækst, fordi døden og mørket til stadighed truer. Derfor må Gud som troens åbenbarede herlighedshåb bære med på det:

Haab, som du er her tilstæde, Er mit Hjertes Liv og Lyst, Regnes skal du til de Spæde, Vænnet af fra Modersbryst, Har ei Haand til Værn og Skjold Mod al Verdens Overvold, Har ei Fod til dig at bære, Har ei Mund til dig at nære.

Du, hvem jeg i Troen kiender, For min Gud, som alting veed, Bær mit Haab paa dine Hænder, Nær det med din Kiærlighed!

Ei da synker det til Jord, Ei det fattes Liv og Ord, Ei det fattes Aand og Tunge

Til med Fryd din Priis at sjunge!

IV 283,1 og 2

Det mest slående er måske den ubekymrede måde, Grundtvig ofte taler om vækst på. Men er der slet ikke noget problematisk ved disse tanker? Strider de ikke mod den lutherske retfærdiggørelseslære? Ligner de ikke pietistisk fromhedslære eller for den sags skyld rationalistisk præstationsteologi? Har Lindhardt ret, når han indordner Grundtvigs vækstsyn under det 19. århundredes romantiske teologi med dens tro på udviklingen?27

Selv om svaret ikke er entydigt, er hovedsagen det. Væksten er kun ubekymret og selvfølgelig, når den (som hos Luther) sker på nådens og tilgivelsens betingelser. Derfor må mennesket til stadighed vende tilbage til Ordets sakramente ved dåb og nadver som vækstens eneste og sande begyndelse og ende: 
Ja, født af Aanden i vor Daab,

Opvoxe skal derefter

Guds Herligheds det lille Haab,

Og daglig samle Kræfter,

Og finde saa ved Herrens Bord

I Kiærlighedens Guddoms-Ord

Alt hvad det higed efter!

IV 300,5

Der hvor væksten bygger på en stadig tilbagevenden til et nøgent og udleveret evangelieord, nutidiggjort i gudstjenestens sakramentord, kan der ikke blive tale om nogen optimistisk, selvhævdende udviklingsteologi. Selv om Grundtvig ved, at Guds ord ikke kan vende tomt tilbage, så er truslen fra mørkets kræfter dog altid en reel trussel, der ikke tillader den døbte at ende i død sikkerhed. Grundtvig siger det selv med klare ord 16. s.e.tr. 1864 (SP, I):

"Ja, kristne Venner, naar som helst den levende Forkyndelse af Jesus Kristus, som han var, som han er til Stede, og som han kommer med sin Faders Velsignelse, naar denne Forkyndelse ophører, da er Guds Herligheds Haab vel derfor ingenlunde dødt i sig selv, thi det er den Jesus Kristus selv, som dør ikke mere; men for det troende Hjærte er Haabet dødt, ja, for os er Herren og Frelseren død, naar vi ikke længer føler os tiltalte med det evige Livs Ord fra hans Læber« (s. 379).

Her er ingen forbehold. Håbet dør, når det ikke længere føler sig tiltalt med 'det evige Livs Ord'. Flere kommentarer skal det citat ikke have. Det taler for sig selv om den håbets dobbelte dimension, der har været det gennemgående tema for dette indlæg.

Man kan godt med Lindhardt sige, at Grundtvig i modsætning til Kierkegaard inddrager fremtiden, som endegyldigt skal føre kraftbeviset. 4.s.e. trin 1864 bruger han selv ordet sikkerhed i den forbindelse, hvor han taler om, at selv den kristne må sukke under forkrænkelighedens lov, "og kan kun trøste sig ved Sikkerheden paa en herlig Gjenløsning fra dens Aag. Dette hænger da paa det nøjeste sammen med vor kristne Trosbekendelse om Vorherres Jesu Kristi Død og Opstandelse med Kjød og Ben og om den Kjødets Opstandelse til det evige Liv, som er hans Menigheds uforkrænkelige Haab« (SP, I, s. 361).

Som så ofte før er trosbekendelsen nøgleordet - men er den også 
blevet et trylleord, der ikke holder mennesket fast på samtiden? Nej! Grundtvig bygger på den allerede indtrufne Kristusbegivenhed, og sikkerheden er en troens og håbets sikkerhed. Væksten er ikke automatisk virkende. Døden er en lige aktuel trussel:

"Saa længe imidlertid Døden som den sidste Fjende ej er fældet, men fælder os alle legemlig som udgaaede Træer, da fristes jo ogsaa vor Tro paa Kjødets Opstandelse til et evigt Liv, og der er altid en Frygt tilbage for Opløsning, som Forklarelsens Haab maa kæmpe med « (s. 363).

Alligevel fortsætter Grundtvig prædikenen med at tale om håbets stadige vækst. Men væksten sker på Guds betingelser, ikke på menneskets. Den erfares i menighedens lovprisning, men den kan aldrig give menigheden ret til at lave regler, der kan sikre fremtiden.

I overensstemmelse hermed skiller Grundtvig ofte kærligheden ud fra trilogien tro, håb og kærlighed. Kærligheden er begyndelsen og grunden:

Kiærlighed er Hjerte-Grunden

Til vor Tro og til vort Haab,

IV 264,3

- og den er faderfavnen, målet for væksten:

Voxende paa Troens Jord, Herlighedens Haab herneden

Til Guds Favn: Guds-Kiarligheden!

$\mathrm{V} 92,11$

"Kiærlighed er Rod og Frugt « hedder det i det foregående vers. I mellemrummet spændt ud mellem disse to kærlighedspoler befinder håbet sig, ikke som et bedrageligt ønske eller som en krampagtig fremtidsforventning, ikke kun som en trøsterig nådegave, men som en gudsrigekraft, en 'Guddoms-Mand', der møder det forvildede menneske i dåben, fødes med det af dåbens tro og vokser med det helt fra den spæde og magtesløse begyndelse - begynder forfra, hvergang den døbte fortvivler. Herlighedshåbet har sin rod her på jorden i den skrøbelige tro, men det glipper ikke, fordi mennesket $\mathrm{i}$ Kristus fik et sandt medmenneske. I Ham åbenbaredes målet. Han 
blev medbeder på det Fadervor, hvori håbet er indgivet mennesket som salighedspant. Det skal vokse og stige, til det når himlen. Da Gud blev menneske, åbnedes vejen for mennesket til Gud, håbet vågnede og vandt retning - det blev en gudsrigevækst i mennesket. Og denne inkarnation og dødeopvækkelse gentages, hvergang dåbens ord lyder.

\section{Slutning}

Det skal være min afsluttende påstand, at Grundtvig livet igennem nærede det personlige håb, at det folkelige og det kristelige håb til slut måtte blive et fælleshåb, ligesom de i skabelsen havde fælles oprindelse. Allerede i 1815 nærede Grundtvig det urimelige håb, at netop Danmark skulle blive den åndelige Maria der "skal undfange og føde Jesum paa ny, gjenføde hans Tro iblandt Folkenes Slægter «28. I 1832 tager han det forbehold, at han ikke mere tror på, at dette vil ske "som ved et Trylleslag ${ }^{29}$. Det kristne budskab kan ikke påtvinges nogen. Det må antages i åndsfrihed. Men forventningen er den samme som i 1815 . Senere må Grundtvig indrømme "at jeg jo i min Ungdom nævnede Danskhed og Christendom saa tit $i$ eet Aandedræt og i saa dunkel en Forbindelse, at man let kunde tænke, jeg paa en eller anden Måde sammenblandede dem«. Men på den anden side opgiver han ikke håbet om kristendommens oplivelse, når blot »Menneske-Naturen og Christendommen levende mødes i fri Vexel-Virkning « ${ }^{30}$.

Den forventning tager til i Grundtvigs sidste prædikener. Nytårsdag 1864 anslår han et tema, der skal blive gennemgående for det følgende års prædikener, idet han minder om »den inderlige Sammenhæng mellem det folkelige og det kristelige, (SP, I, s. 295). Nytårsdag 1865 refererer Grundtvig direkte til prædikenen et år tidligere:

"men jeg meddelte ogsaa mine troende Tilhørere den Grund, hvorpaa mit Haab hvilede, den nemlig, at det folkelige og det kristelige i Danmark baade lignede hinanden saa meget og var gjennem et langt Tidsrum blevet saa fast sammenknyttede, at Vorherre Jesus Kristus aldrig ville adskille dem, som Gud har sammenføjet» (SP, I, s. 403). 
Grundtvig er iøvrigt ikke sen til at ud nytte, at nytårsdag 1865 falder på en søndag:

»Og jeg kalder det derfor et godt Varsel, at den borgerlige Nyaars-Dag falder i Aar paa en Søndag og smelter saaledes sammen med en af Herrens egne Dage; thi det passer godt med at Riget og Folket skal frelses i Jesu Navn og for den Ligheds og den Sammenhængs Skyld, som der er mellem Danmarks hjærtelige og Jesu Kristi aandelige Folk« (s. 404).

Håbet om folkets frelse synes her at stå usvækket hos den gamle Grundtvig. Dette giver mig anledning til at opponere mod Thaning, ikke fordi han i sin disputats understreger adskillelsen mellem menneskeligt og kristeligt, men fordi han bliver stående derved. Efter min mening hører der til en hel antropologi både en tydning af menneskets oprindelse og af dets mål. ${ }^{31}$ Det betyder for Grundtvig, at både menneskeligt $o g$ kristeligt bliver en forudsætning - det menneskelige for at kunne føle sig tiltalt af Guds Ord - det kristelige for at mennesket under denne tiltale kan nå sit mål. Basis for dette syn er det levende ords fri vekselvirkning. Men hvis man adskiller menneskeligt og kristeligt for adskillelsens egen skyld, så forbliver denne vekselvirkning en teoretisk størrelse, der ikke må ogikke kan føre til noget. Så gøres adskillelsen ahistorisk, idet vekselvirkningen tages ud af det dynamiske historiesyn, den rettelig hører hjemme i hos Grundtvig. Jeg er overbevist om, at den gamle Grundtvig i overensstemmelse hermed følte sig nærmere sit håbs opfyldelse om "et kristeligt Folkeliv fra Slægt til Slægt « voksende indtil fuldendelsen (SP, II, s. 337).

Disse påstande kræver i høj grad en solidere underbygning bl.a. gennem undersøgelser af det folkelige håb hos Grundtvig. Det arbejde ligger imidlertid uden for denne opgaves rammer, der alene er bestemt ud fra et teologisk synspunkt. Opgaven skal derfor slutte med det åbne spørgsmål, ikke om hvad adskillelsen mellem menneskeligt og kristeligt betyder, men om hvori sammenhængen mellem menneskeligt, folkeligt og kristeligt håb består hos Grundtvig?

\footnotetext{
Noter

1. Ordbog over det danske Sprog, Kbh. 1925, og Dansk Ordbog for Folket, Kbh. 1907.

2. 4.s.i. advent 1832 (PF, s. 113).

3. Fra H. G. Clausens "Prædikener, holdne i Frue-Kirke...", III, 1805, s. 114.
} 
4. 2.s. i advent 1813 (BP, s. 112-13).

5. BP, s. 114.

6. Jvf. "Om menneskets Vilkaar", hvor Grundtvig taler om den uforenelige modsætning mellem sandhed og løgn og derefter slutter: "Noget kan ikke baade være og ikke være i samme Mening, og det kalde vi Modsigelsens Grundsætning“ (VU, II, s. 264).

7. Prædikenen på Mariæ Beb. 1815 (BP, s. 291) synes at være en af de få prædikener, der står i direkte gæld til tankerne fra arbejdet med Verdens Krøniken (Jvf. min emnekreds).

8. Fra fortalen til Nyaars-Morgen (VU, VII, s. 370).

9. sst.

10. Jvf BP, s. 112.

11. Se Kingos udlægning af samme skriftsted (DDS 230, 2), se ovenfor.

12. For Viggo Mortensen bliver håbet det eneste svar på lidelsens problem og det $\mathrm{i}$ udtryk og vendinger, der ligger meget nær Grundtvigs, hvorfor man godt kan undre sig over, at Grundtvig ikke i højere grad bliver inddraget hos Viggo Mortensen, (se Lidelsens Problem, Kbh. 1976, s. 134-139).

13. Også tidligere i prædikenen ser vi, at Grundtvig er ved at overvinde skriftproblemet: "Vi erkiende ingen Pave, ingen ufeilbar Fortolker af Guds Ord, han hedde saa Jakob eller Judas eller Morten Luther men bedømme dem med evangelisk Frihed efter det Ord som skal os alle dømme..." (s. 2).

14. Dansk Kirkesangs Arsskrift 1971-72, s. 127. Iøvrigt vil III 86 herefter gå under den gængse betegnelse "De Levendes Land".

15. SP, I, s. 14.

16. Måske har Irenæus været med til at hjælpe Grundtvig frem til dette. I hvert fald kunne den lidt tøvende sætning fra 1823 "..ogsaa med disse vore Legemer.." (s. 133) tyde på, at han har læst Irenæus på dette tidspunkt bl.a. den 5. bog, som Grundtvig i 1827 oversætter til dansk under titlen: "Om Kiødets Opstandelse og det evige Liv«.

17.25.s.e.trin. 1823 , s. 10.

18. Bemærk f.eks. i bilag I A., hvorledes Grundtvig henimod slutningen lader håbet klares igennem udtrykkene: 'taaget Stjerne - Lede-Stjerne - Solen selv', og iøvrigt hvorledes prædikenen slutter med nogle enkeltstående sætninger med nat/dag-motivet og med en opregning af bibelcitater.

19. Jvf. Kaj Thaning: Menneske først- Grundtvigs opgør med sig selv, 1963, s. 534.

20. 2.s. i advent 1825 , s. 6 .

21. Jvf. Thodbergs undersøgelser af forholdet mellem forkyndelsesproklamationer og gudstjenestens ritualord i Grundtvig-Studier 1975, s. $7 \mathrm{ff}$.

22. Jvf. Thodberg i Dansk Kirkesangs Arsskrift 1973-74, s. 42ff.

23. Jvf. Valdemar L. Ludvigsens emnekreds (her s. 171).

24. Skærtorsdag 1855 (Lindhardt: Konfrontation, K bh. 1974, s. 83).

25. Balles ritual fra 1783 (se En glemt dimension..., s. 16).

26. Jvf. Erik Krebs Jensens emnekreds (her s. 82).

27. "Men den virkelig afgørende modsætning ligger $\mathrm{i}$ at hvor Kierkegaard vil holde mennesket fast på samtiden - eller øjeblikket - inddrager Grundtvig (beroligende) den fremtid som endegyldigt skal føre kraftbeviset. Med det 19. århundredes romantiske teologi deler han troen på udviklingen..." (Lindhardt, Konfrontation, s. 217).

28. Mariæ Beb. 1815 (BP, s. 305).

29. Mariæ Beb. 1832 (PF, s. 26).

30. Dansk Kirketidende 107/1847.

31. Jvf. tankerne i "Om Menneskets Vilkaar«, 1813ff., hvor Grundtvig spørger om menneskelivets "hvorhen, hvorledes og hvorfra" (VU, II, s. 265). 


\section{5}

Bilag I, A: Grundstrukturen, når alt andet end håbsudtryk er skåret væk fra prædikenen:

verdsligt håb

Verdens Trøst og Glæde ogsaa beroer blot paa et Haab, og det paa et forfængeligt Haab, som idelig bedrager og aftager.

-hvor meget det end skuffede, dog var det høieste Haab, der fandtes paa Jorden fælles håb

et grundfast uforkrænkeligt af Aanden beseglet, levende Håb

-frelste $i$ Haabet, vi fryde os $i$ Guds Herligheds Haab

-frydefulde Haab

- vor christne Tro og det derpaa grundede, levende, salige Haab

-uforkrænkelige Haab

-Guds Herligheds Haab

-de Christne, der fryde

sig i Guds Herligheds Haab -dette Guds Herligheds

$\mathrm{Haab}$

- dette Haab er dog Perlen -Verden maa misunde os Guds Herligheds Haab

og beskiæmmes af Guds Børns Haab, der aldrig skuffer, men voxer - det Guds Herligheds Haab som piner og beskiæmmer dem

er der...nogen Lyk-

ke for Menneskens

Børn, som bestaaer

$i$ andet end Haab

-den hele Skabning

...glæader sig i

Haabet

- et dunkelt Fri-

heds Haab

-dette Haab har

Verden først be-

istridt og siden

bespottet

-Mennesket lever

i Haabet

-Haabets Stjerne

-to saadanne Stjer-

ner, kun tvende

Haab

det ene er Verdens.

det Andet er Guds Herligheds Haab

-det begynder med

det evige Liv og

ender med den e-

vige Død

-oprinder som Iys,

men taber sig...

i Mørke

-begynder med Sik- 
verdsligt håb

kerhed og ender med Fortvivlelse

-det begynder som Haab om evigt Liv

-unaturlige fortvivlede $\mathrm{Haab}$

-det af sindige, rasende

Haab, efterhaanden....at

glemme sig selv... at døe

ubevidst at nedsynke $i$ en

evig Selv-Forglemmelse,

som en evig Død...det er

Verdens sidste $\mathrm{Haab}$

-styrte sig fra Taarne og

Broer...Drukkenskab, Krig,

Verdens-Tummel...

-Verdens Trøst...den Ind-

bildning at alt Haab er bedrageligt... dog uundværligt -klogest at vælge det Haab, der skuffer bedst og brister sidst

-det er nu Verdens Haab som

den selv forbander og kal-

der...bedrageligt.

-dem der ere uden Haab eller bedrage deres Sjæl med et

falsk. Haab. $\underline{\text { kristeligt håb }}$

- men nu Guds Børns Haab, Guds Herligheds Haab det baade begynder og ender med det evige Liv, begynder aldrig saa smilende...fuldendes endnu skiønnere, det oprinder som en taaget Stjerne

-Lede-Stjerne...opvarme og oplive

-er det dog i Grunden Solen selv i Aandernes Rige, som Apostelen siger Christus $i$ eder er Herlighedens Haab -naar Haabet nu saaledes begynder at blive levende i Kiærlighed, da giver det sig tilkiende $i$ hele vort Levnet

oplade Øiet for Guds Herligheds Haab i Christo Jesu, og kiøbe det i Troen med Forsagelse af den Verden de veed bedrager dem

-Guds Herligheds Haab er om Natten

vor Trøst og om Dagen vor Glæde

-For Verden er det om Natten til

Spot og om Dagen til Gru

- Men hvad vi kalde Dag kalder Verden

Nat, hvad vi kalde Mørke, kalder

Verden Lys 
Bilag I, B: Den struktur, der blev beskrevet i bilag I, A, synes at kunne genfindes $i$ "De Levendes Land", 16.s.e.trin. og 4.s. e.trin.1823:

skabelseshåb og

-længsel

forvrænget håb og

det genfødte kristelige længsel

$\underline{\text { håb }}$

vers $1-3$

vers $4-6$

vers $7-13$ (spec.vers 10)

16.s.e.trin.:

denne Iængsel boer Skygge - blommede han er os nær som Ordet $i$
$i$ din Barm, den er Bobler - Røg - Damp $i$ vor Mund og $i$ vort Hjer $i$ din Barm, den er dig nødvendig ind-

- Ere - Vælde - te

prentet...af den u- lyve - hadede og

synlige Skaberhånd, bekæmpede - bedrader dannede dig som ger

Leer

4.s.e.trin.:

den Iængsel...der som et vidunderligt Mindes-Mærke om Sjælens aandelige, himmelske Udspring, findes $i$ hvert

Menneskes Hjerte

glemme og kvæle Digten og Tragten - glemme - Dødens Budskab for de Syge, en Trøst kun for de Ligegyldige saa prædiker Aanden Haab, et Haab som beskiæmmer Forkrænkelighed - boer kun dette Haab levende i os

Sammenhængende understruktur 16.s.e.trin.: Gak til ham der med din Iængsel som vel maa kaldes en bedrøvet Enke, hvis eenbaarne Søn, hvis Haab de bære til Graven, gak til ham der og høre...om han ikke siger Kvinde græd ikke og til dit Haab: stat op, og see, om det ei viser sig lyslevende og synker $i$ din Længsels Favn og føder Jesu Christi Priis paa din Tunge

Sammenhængende understruktur 4.s.e.trin.: det store Haab, som svæver over Skabningen og aabenbarer sig som en dyb, uforkrænkelig Længsel, i den bestandige Kamp den bestandige Gienfødelse, dette Haab boer levende $i$ os

[De valgte udtryk og citater er kun enkelte af flere, der kunne bruges til at vise denne struktur] 